Збірник наукових праць Української державної академії залізничного транспорту

УДК 629.4.027

Канд. техн. наук І.Д. Борзилов

Cand. of techn. sciences I.D. Borzilov

\title{
ЗАБЕЗПЕЧЕННЯ ЯКОСТИ РЕМОНТУ ВАГОНІВ В УМОВАХ РЕФОРМУВАННЯ ГАЛУЗІ
}

\section{PROVIDING OF QUALITY OF REPAIR OF CARRIAGES IN THE CONDITIONS OF REFORMATION OF INDUSTRY}

\section{Представив д-р техн. наук, професор І.Е. Мартинов}

Вступ. Укрзалізниця удосконалюе ремонтну та експлуатаційну бази вагонних депо. Триває розподіл депо за типами робіт, які в них проводяться. Реформування депо має за мету розділити витрати на ремонт та експлуатацію вагонів. Ремонт вагонів - це 
значна стаття витрат. Настільки значна, що вагоноремонтні підприємства неохоче беруть у планові ремонти вагони з великим обсягом робіт. У нових умовах господарювання, коли відбудеться закріплення ремонтних депо за підприємствами, на балансі яких знаходяться вагони, доведеться їх відновлювати незалежно від трудомісткості робіт. Також має підвищитися якість проведення ремонтів, оскільки тепер ці вагони будуть складати інвентарних парк цих підприємств.

Постановка проблеми. В умовах реформування галузі необхідними $\epsilon$ підходи до забезпечення якості ремонту вагонів. Оскільки сьогодні детального контролю дотримання якості ремонту немає в депо, то інженер 3 приймання вагонів фізично не в змозі перевірити якість ремонту та стан всіх найбільш відповідальних вузлів і деталей вагонів. За таких умов не можливо гарантувати прийнятний рівень якості планового ремонту вагонів i, як наслідок, безпеку руху поїздів. Вочевидь, існує необхідність підвищення якості планових ремонтів вагонів. Реалізація цього, у свою чергу, дозволить підвищити рівень безпеки руху поїздів і корисну віддачу кожного вагона за рахунок зменшення часу простою у неробочому стані.

Аналізи останніх досліджень i публікацій. Проблеми забезпечення якості ремонту вагонів досліджувалися в роботах [1-3]. Однак слід відмітити, що в наш час не існує моделі впливу на якість ремонту радикальних змін у технологічних процесах, в організації праці, в економічних механізмах i переході на інший етап функціонування вагоноремонтних підприємств. Результати аналізу останніх досліджень і публікацій показують, що ще не остаточно вивчені механізми для створення передумов щодо підвищення рівня якості ремонту вагонів.

Мета статті. Визначити шляхи забезпечення якості ремонту вагонів в умовах реформування галузі.
Постановка завдання. Для рішення поставленої мети необхідно створити модель інформаційного контрольованого технологічного процесу i на їі підставі запропонувати шляхи модернізації управління якістю ремонту вагонів i впровадження системи, яка б забезпечила ефективність управління технологічним процесом і контролем за випуском готової продукції вагоноремонтними підприємствами.

Виклад основного матеріалу. У вагонних депо здійснюється контроль: вхідний - при надходженні вагонів у ремонт; операційний i проміжний - y виробничих дільницях і відділеннях у процесі ремонту складальних одиниць i деталей; вихідний - на позиції здаванняприйняття вагона після його ремонту. Контроль здійснюється бригадирами, майстрами, заступником начальника депо 3 ремонту, інженером 3 приймання вагонів. До контролю залучаються технологи й інші працівники депо.

Разом 3 тим детального контролю дотримання технології ремонту на вагоноремонтних підприємствах немає, і це означає, що неможливо перевірити якість ремонту і стан всіх критичних вузлів i деталей вагонів. Говорити в таких умовах про якусь гарантію на якісний плановий ремонт не доводиться. Про це свідчить статистика: у середньому кожен вантажний вагон, випущений з планового ремонту, за час гарантійного пробігу потрапляє у пункт технічного обслуговування 3 відчепленням 4 рази.

Тому на сучасному етапі необхідно впровадити на вагоноремонтних підприємствах керування якістю ремонту вагонів, заміни візуального контролю на інструментальний, удосконалювання засобів виміру 3 погляду підвищення точності й автоматизації вимірів, впровадження стендів для випробування окремих вузлів, автоматизації запису результатів вимірів 3 переходом до безпаперових технологій. 
Слід ураховувати, що теперішній стан розвитку інформаційних технологій [4] створює об'єктивну основу для впровадження у вагоноремонтне виробництво так званого інформаційного конт- рольованого технологічного процесу.

Розглянемо модель інформаційного контрольованого технологічного процесу $S(T)$ на вербальному рівні (рис. 1) як множину, яка складається із підмножин:

$$
S(T)=\left\{I d n^{T}, \operatorname{Prp}^{T}, A t r^{T}, X^{T}, Y^{T}, Q^{T}, C^{T}, S t r^{T}\right\}
$$

де $I d n^{T}$ - ідентифікатор $S(T)$;

$\operatorname{Prp}^{T}$ - множина цілей $S(T)$;

$A t r^{T}$ - множина загальносистемних атрибутів $S(T)$;

$X^{T}=\left\{x_{1}{ }^{T}, x_{2}{ }^{T}, \ldots, x_{n}{ }^{T}\right\}$ - множина вхідних впливів $S(T)$;

$Y^{T}=\left\{y_{1}{ }^{T}, y_{2}{ }^{T}, \ldots, y_{m}{ }^{T}\right\}$ - множина вихідних характеристик $S(T)$;

$Q^{T}=\left\{q_{1}^{T}, q_{2}^{T}, \ldots, q_{k}^{T}\right\}$ - множина впливів зовнішнього середовища;

$C^{T}=\left\{c_{1}^{T}, c_{2}^{T}, \ldots, c_{h}^{T}\right\}$ - множина внутрішніх якостей $S(T)$;

$S t r^{T}=\left\{T, R^{T}\right\}$ - структура $S(T)$;

$T$ - множина елементів $S(T)$;

$R^{T}$ - множина зв'язків між елементами $S(T)$.

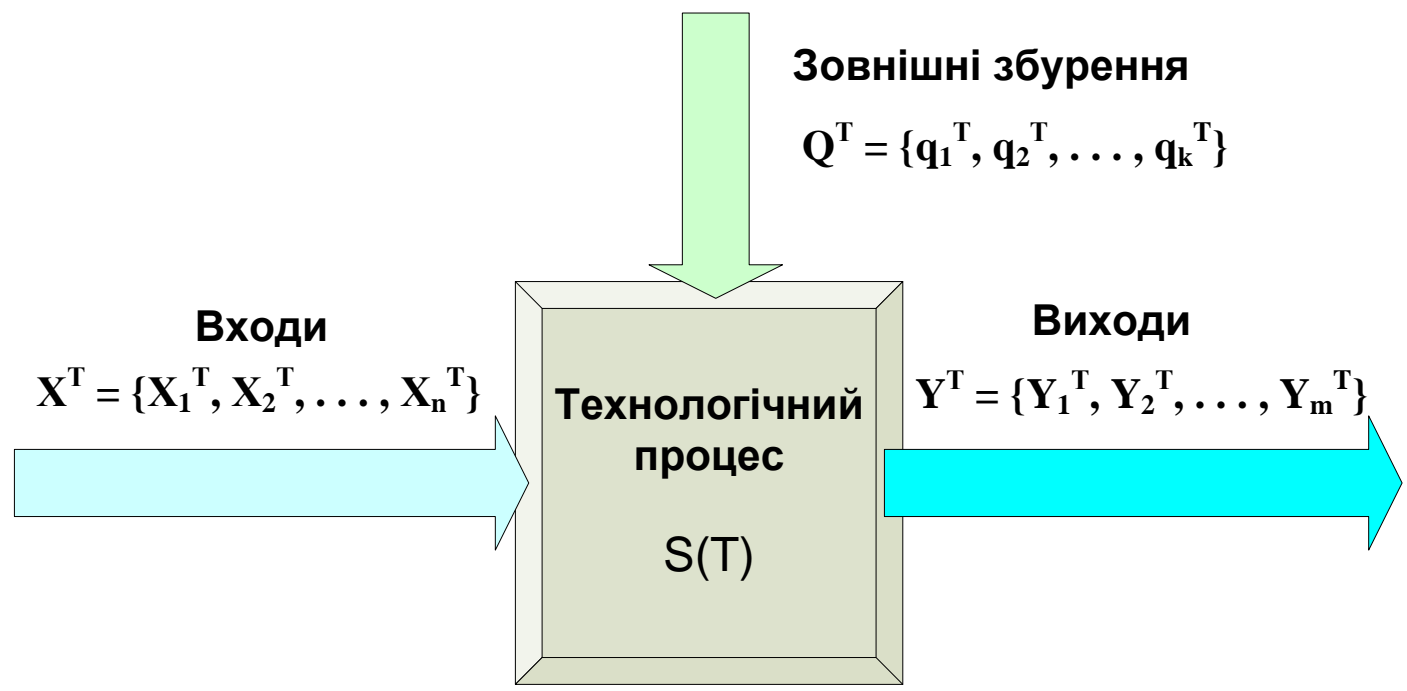

Рис. 1. Узагальнена принципова схема інформаційного контрольованого технологічного процесу

Ідентифікатор процесу $\left(I d n^{T}\right)$ являє собою сукупність двох визначень «позначення технологічного процесу» i «найменування технологічного процесу».

$$
\text { У якості множини цілей }
$$
інформаційного контрольованого технологічного процесу $\left(\operatorname{Prp}^{T}\right)$ виступають загальне підвищення ефективності роботи вагоноремонтного підвищення якості ремонту вагонів; зниження трудомісткості та собівартості ремонту; скорочення тривалості технологічного процесу ремонту.

У якості загальносистемних атрибутів інформаційного контрольованого технологічного процесу $\operatorname{Atr}^{T}$ виступають типи вагонів, що ремонтують; види ремонту вагонів, що виконують на вагоноремонтному підприємстві; призначення технологічного процесу 
(контроль, розбирання, складання, транспортування та ін.).

Входи $X^{T}=\left\{x_{1}^{T}, x_{2}{ }^{T}, \ldots, x_{n}{ }^{T}\right\}$ і виходи $Y^{T}=\left\{y_{1}{ }^{T}, y_{2}{ }^{T}, \ldots, y_{m}{ }^{T}\right\}$ інформаційного контрольованого технологічного процесу визначаються його функціональним призначенням, яке полягає в перетворенні значень параметрів, що характеризують технічний стан вагонів, які поступають у ремонт, у значення цих параметрів, що встановлені нормативно-технічною документацією для вагонів, що випускають 3 ремонту.

Множинами впливів зовнішнього середовища для вагоноремонтних підприємств $Q^{T}=\left\{q_{1}^{T}, q_{2}^{T}, \ldots, q_{k}^{T}\right\}$ можуть бути зміни виробничої програми ремонту вагонів; технічний стан вагонів i їx складових частин; впровадження нових технологій i засобів технологічного оснащення; зміни правил ремонту; дії виконавців; стан засобів технологічного оснащення.

Внутрішні якості $\left(C^{T}\right)$ i структура $\left(\mathrm{Str}^{T}\right)$ інформаційного контрольованого технологічного процесу на вербальному рівні моделювання описують переліком елементів і їх якостей і зв'язків.

До внутрішніх якостей $C^{T}=\left\{c_{1}{ }^{T}, c_{2}{ }^{T}\right.$, . . . , $\left.c_{h}{ }^{T}\right\}$ елементів інформаційного контрольованого технологічного процесу будемо відносити значення параметрів технологічних процесів, операцій i переходів, що характеризують засоби технологічного оснащення (обладнання, пристосування, інструмент); професійний склад i кількість виконавців; основний, допоміжний, штучний та підготовчозаключний час; витрачання матеріалів i запчастин; місце проведення робіт та умови праці; параметри, що контролюють; режими обробки.

В основу розроблення моделі інноваційного технологічного процесу ремонту вагонів i їх складових частин покладено блочно-ієрархічний підхід (рис. 2), оскільки він знаходить широке застосування при описі багатьох об'єктів і зараз альтернативи йому не існує.

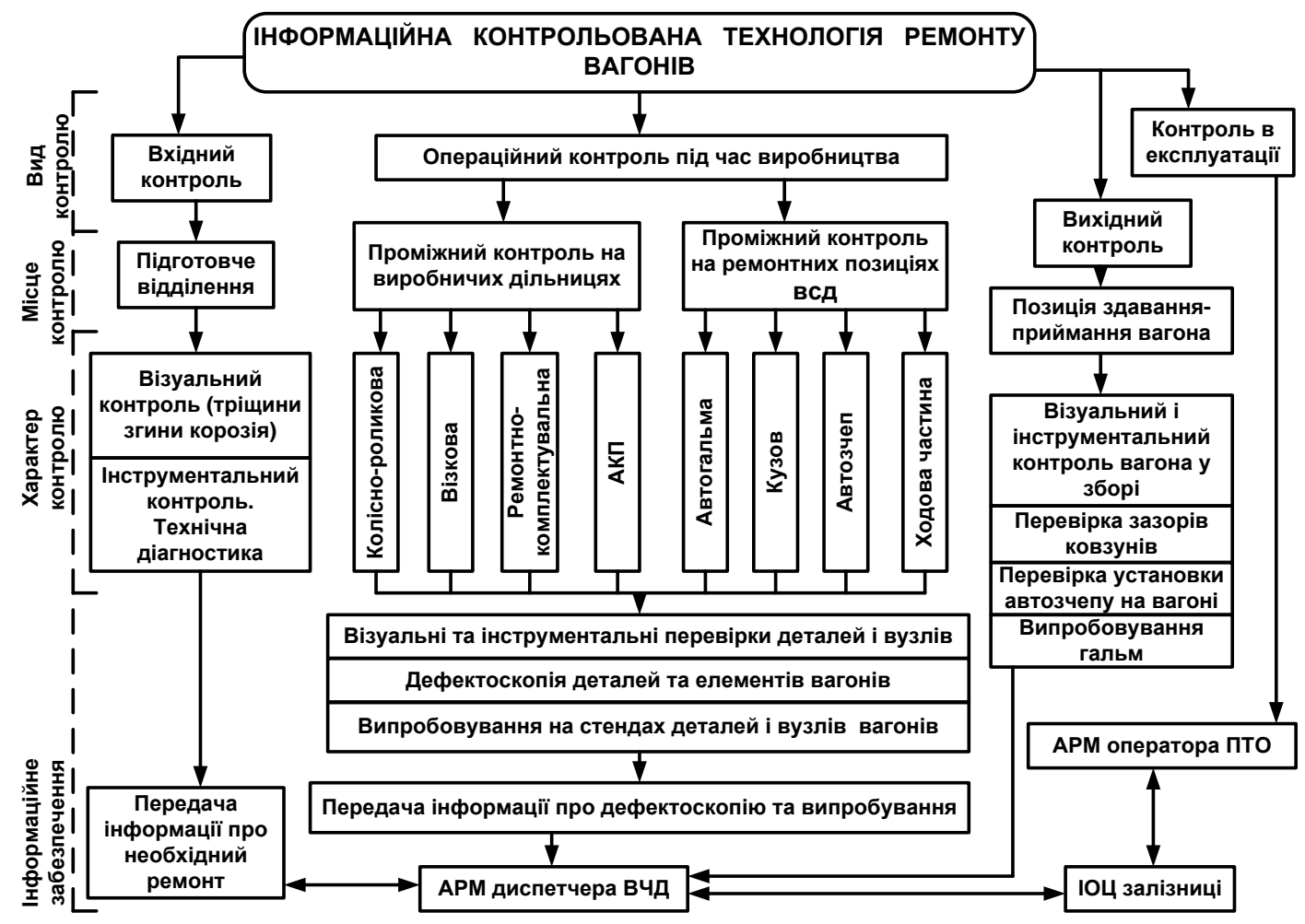

Рис. 2. Схема інформаційної контрольованої технології ремонту вагонів 
Ефективність

інформаційної контрольованої технології ремонту вагонів обумовлена зниженням впливу людського чинника за рахунок введення інформації безпосередньо 3 технологічного устаткування, застосування автоматичного аналізу придатності до ремонту вузлів і деталей, а також автоматичного підбору критичних вузлів і деталей при кінцевому складанні. Завдання, що виконується, можна сформулювати в такий спосіб: за отриманими даними про технологічний процес складається прогноз протікання технологічного процесу 3 реалізацією плану управляючих впливів (у тому числі зміни режимів роботи ремонтного устаткування), що забезпечують відповідність у певний момент часу стану технологічного процесу деякому екстремальному значенню узагальненого критерію якості ремонту й продуктивності виконуваних робіт.

Для вирішення цього завдання необхідне обгрунтування сукупних показників якості ремонту вузлів і деталей i часу виконання операцій технологічного процесу.

Показник якості ремонту можна визначити як

$$
G_{k}=\sum_{i=1}^{n} \frac{g_{f_{i}}}{g_{N_{i}}}=\sum_{i=1}^{n} k_{i},
$$

де $g_{N i}$ - нормована комплексна оцінка виконання $i-i$ операції;

$g_{f i}$ - фактична комплексна оцінка $i-i$ операції;

$k_{i}=g_{f i} / g_{N i}-$ коефіцієнт, що враховує повноту виконання $i-i ̈$ операції (вірогідність виконуваних вимірів, точність обробки виробів і т. д.);

$n$ - кількість операцій технологічного процесу.
Показник часу виконання операцій технологічного процесу визначається як

$$
U_{t}=\sum_{i=1}^{n} \frac{t_{f_{i}}}{t_{N_{i}}}=\sum_{i=1}^{n} k_{o i}\left(2-k_{o i}\right),
$$

де $t_{N i}-$ нормований час виконання $i-i$ операції, хв;

$t_{f i}$ - фактичний час виконання операції, $\mathrm{XB}$;

$k_{o i}=t_{f i} / t_{N i}-$ коефіцієнт, що враховує час виконання $i-\ddot{i}$ операції технологічного процесу.

Обгрунтуванням форми подання показника $U_{t} \in$ небезпека відхилення коефіцієнта $k_{o i}$ від значення, рівного одиниці. При $k_{o i}<1$ може бути неякісне виконання операцій, а при $k_{o i}>1$ відбудеться порушення технологічного процесу. дорівнює

Комплексний показник якості

$$
k=\alpha_{1} \sum_{i=1}^{n} k_{i}+\alpha_{2} \sum_{i=1}^{n} k_{o i}\left(2-k_{o i}\right)
$$

де $\alpha_{1}, \alpha_{2}-$ коефіцієнти вагомості показників якості.

Забезпечує виконання цих нетривіальних завдань програмний продукт “Програм Лайн: ремонт вагонів", створений компанією "Мікротест". Програмний продукт призначений для використання на вагоноремонтних підприємствах як система управління якістю. Він передбачає створення i pyx ремонтного паспорта вагона паралельно технологічному ланцюжку ремонту i наповнення його інформацією про роботи, проведені над вагоном i його вузлами, їх технічне перебування на різних стадіях ремонту, комплектацію вагона, що випускається, якість виконання ремонту, витрати на ремонт і т.ін. (рис. 3). 


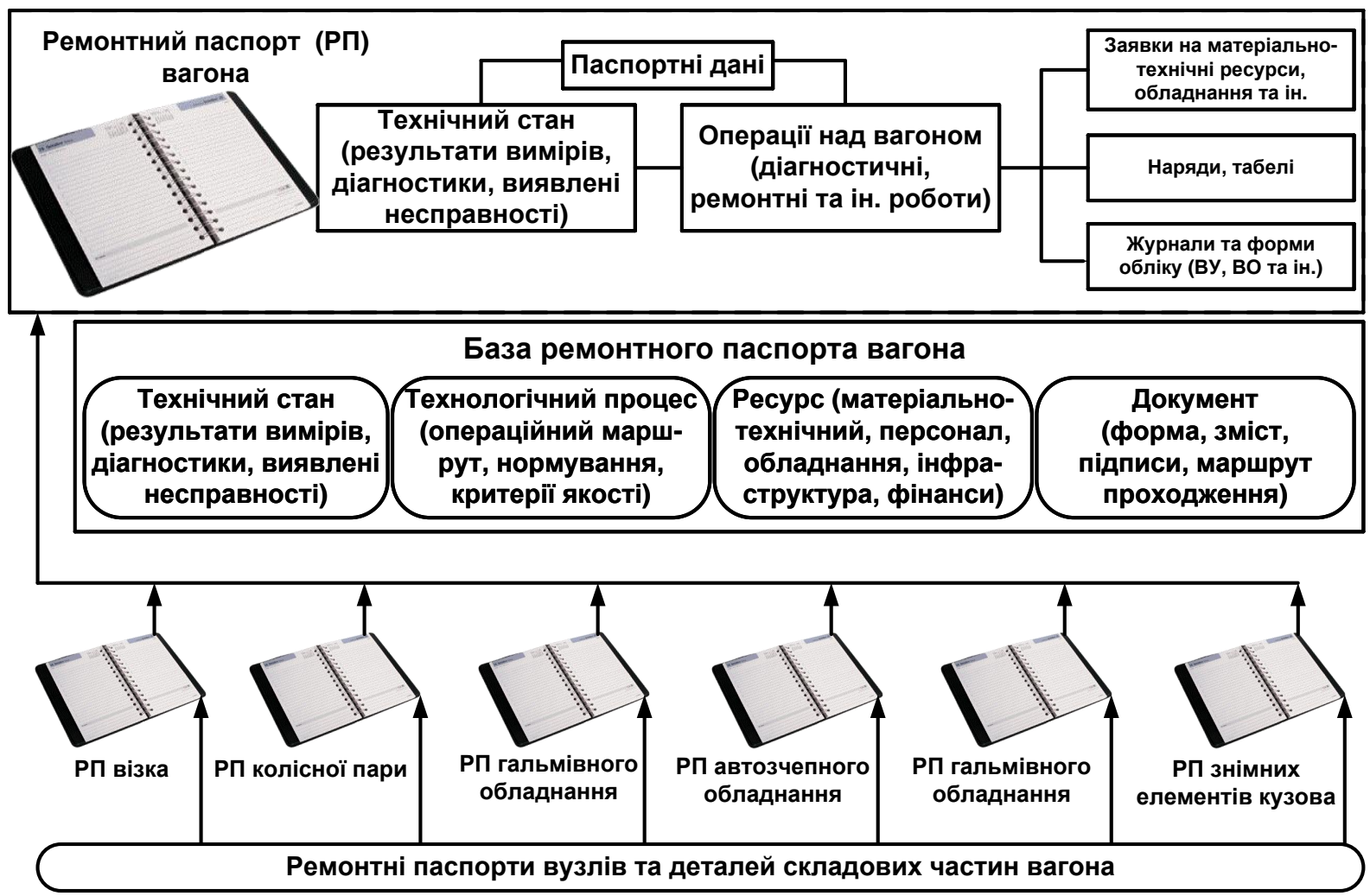

Рис. 3. Зміст ремонтного паспорта вагона

Це у свою чергу дозволяє управляти якістю ремонтів за рахунок покрокового обліку виконуваних робіт, контролю технічного стану вузлів i дотримання технологічних процесів.

Застосування цієї системи має незаперечні переваги:

- використання електронного документообігу;

- створення i ведення електронного паспорта вагона i його деталей, який містить вичерпну інформацію про вагон, проведені ремонти, технічний стан до i після кожного ремонту.

Інформація 3 ремонтного паспорта необхідна для ухвалення рішення про приймання вагона з ремонту, подальшого моніторингу його технічного стану, планування i виконання оптимальних ремонтів надалі i для обгрунтування рахунків за ремонт. Ці ж дані використовуються такими системами, як постачання, бухгалтерія, кадри і так далі.
Весь технологічний ланцюжок від входження вагона в депо до виходу відремонтованого, розбито на функціональні дільниці, кожній 3 яких відповідає своє автоматизоване робоче місце (AРM). У кожному АРМі основного виробництва відбувається:

- автоматичне (3 технологічного устаткування) i ручне (3 терміналу) введення даних за виконаними операціями (виміри, діагностика, розбірні, відновні, складальні операції і так далі), витратами на виконання (матеріали, час і так далі);

- автоматичний і експертний контроль технічного стану вузла, що ремонтується (відповідність допускам, наявність дефектів i так далі) за фактом введення даних вимірів, діагностики і випробувань, ухвалення рішення про подальшу долю вузла;

- автоматичний і експертний контроль дотримання технології виконання операцій (послідовність кроків, норми витрат матеріалів, часу, кваліфікація виконавця, 
стан устаткування, умови і так далі), ухвалення рішення про якість виконання даної операції і перехід до наступної;

- автоматичний i ручний облік i контроль комплектації вагона.

На сьогодні більшість вузлів вагона не мають унікальних номерів. Разом $з$ тим вимоги до якості ремонту вимушують відстежувати, як ремонтується кожен з них. Тому в межах вагонного депо неномерні вузли отримують тимчасові номери (ярлики зі штрих-кодом), які привласнюються їм у процесі ремонту. Після цього демонтовані і пронумеровані на час ремонту вузли i деталі поступають на відповідні ремонтні дільниці.

Інтеграція системи 3 дефектоскопами i вимірювальними комплексами дозволяє автоматично отримувати результати неруйнівного контролю і аналізувати стан виробів.

На деталі, що поступили на ремонтні дільниці, і на вузли за наслідками неруйнівного контролю формуються наряди на усунення виявлених несправностей, а потім автоматично відстежується дотримання всього ремонтного циклу 3 усунення кожної несправності.

Система фіксує в числі справних деталі відремонтовані і перевірені. Із списку придатних до експлуатації виробів автоматично формуються комплекти 3 урахуванням геометричних, вікових і інших особливостей кожної деталі і відповідно до вимог щодо вузлів і деталей, що висуваються при установленні на конкретний вагон.

На кожній дільниці система автоматично веде журнал вузлів і деталей, що знаходяться в зоні відповідальності дільниці, показуючи поточну операцію, що здійснюється 3 кожною $з$ деталей.

Ремонтні паспорти всіх вузлів і деталей, які формуються і ведуться впродовж всього ремонтного циклу, при збиранні деталей у вузли і при постановці на вагон «зливаються» в загальний ремонтний паспорт вагона, надаючи керівникові або інженеру 3 приймання вагонів можливість переконатися в якості ремонтних робіт, що виконані на вагоні і його вузлах. Доступ до такої інформації організується по мережі, тому керівник може оцінювати роботу депо як зі свого кабінету, так i знаходячись далеко за його межами.

Висновки 3 дослідження. В умовах реформування галузі необхідними $€$ нові підходи до забезпечення якості ремонту вагонів; модель впливу на якість ремонту радикальних змін у технологічних процесах, в організації праці, економічних механізмах i переході на інший етап функціонування вагоноремонтних підприємств. В основу розробленої моделі інноваційного технологічного процесу ремонту вагонів та їх складових частин покладено блочно-ієрархічний підхід. Ефективність інформаційної контрольованої технології ремонту вагонів обумовлена зниженням впливу людського чинника за рахунок введення інформації безносередньо 3 технологічного устаткування, застосування автоматичного аналізу придатності до ремонту вузлів і деталей, а також автоматичного підбору критичних вузлів і деталей при кінцевому складанні.

\section{Список літератури}

1. Борзилов, І.Д. Автоматизована система контролю технологічного процесу [Текст] / І.Д. Борзилов, Г.О. Ніколаєнко // Науково-технічний журнал. - К., 2010. - № 1(62). - С.66-68.

2. Борзилов, І.Д. Інноваційна стратегія розвитку системи технічного утримання вагонів [Текст]/ І.Д. Борзилов, М.В. Ігнатенков // Зб. наук. праць Укр. держ. акад. залізнич. трансп. Харків: УкрДАЗТ, 2010. - Вип. 114. - С. 65-69.

3. Борзилов, І.Д. Моделювання інноваційного технологічного процесу ремонту вантажних вагонів та їх складових частин [Текст] / І.Д. Борзилов, С.А. Грабелко // Зб. наук. праць Укр. держ. акад. залізнич. трансп. - Харків: УкрДАЗТ, 2012. - Вип. 128. - С. 201-205. 
4. Вальков, В.М. Автоматизированные системы управления технологическими процессами [Текст] / В.М. Вальков, В.Е. Вершинин. - Л.: Политехника, 1991. - 266 с.

Ключові слова: якість ремонту, інформаційна контрольована технологія, ремонтний паспорт, вагони.

\section{Анотаціï}

Наведено модель інформаційного контрольованого технологічного процесу ремонту вагонів та їх складових частин. Її ефективність у забезпеченні якості ремонту вагонів обумовлена зниженням впливу людського чинника за рахунок введення інформації безпосередньо з технологічного устаткування, застосування автоматичного аналізу придатності до ремонту вузлів і деталей, а також підбору вузлів і деталей при кінцевому складанні.

Приведена модель информационного контролируемого технологичного процесса ремонта вагонов и их составных частей. Ее эффективность в обеспечении качества ремонта вагонов обусловлена снижением влияния человеческого фактора за счет введения информации непосредственно с технологического оборудования, использования автоматического анализа пригодности к ремонту узлов и деталей, а также подбора узлов и деталей при конечной сборке.

A model over of the informative controlled technological process of repair of carriages and their component parts is brought. Her efficiency in providing of quality of repair of carriages is conditioned by the decline of influence of human factor due to introduction of information directly from a technological equipment, uses of automatic analysis of fitness to repair of knots and details, and also selection of knots and details at the eventual assembling. 